Ковшун Н. Е., к.е.н., професор, Шевченко І. В., здобувач (Національний університет водного господарства та природокористування, м. Рівне)

\title{
ОПТИМІЗАЦІЯ ФУНКЦІОНУВАННЯ I РОЗВИТКУ ЛОКАЛЬНИХ І НАЦІОНАЛЬНИХ ТРАНСПОРТНИХ ПІДСИСТЕМ В УМОВАХ ІНТЕГРАЦІЇ
}

Доведено необхідність вдосконалення нормативно-законодавчого, організаційного і господарчого регулювання транспортного ринку. Проаналізовано фактори, які впливають на ефективність процесу транспортування. Досліджено доцільність використання концепту Адізеса при розробці інтеграційних стратегій розвитку транспортних систем.

Ключові слова: локальні транспортні підсистеми, концепція Адізеса, ефективність процесу транспортування, інтеграційні стратегії розвитку транспортних систем.

Постановка проблеми. Транспорт здійснює перевезення в межах виробництв, між підприємствами, регіонами і країнами, суттєво впливає як на глобальну економічну систему, так і на економіку України. Цей вплив на суспільне життя - різноманітний і багатоплановий: транспорт сприяє географічним і структурним зрушенням у розміщенні виробничих сил, забезпеченню економічного росту, зміні технологічного укладу і способу життя, покращенню або погіршенню життєвого рівня народу. Забезпечуючи міжнародний розподіл праці, масовий туризм і культурний обмін, транспорт є однією із основних причин виникнення глобальних змін у світовій економіці, культурі і міжнародних відносинах [1]. Потоки товарів, людей і капіталу в найбільших економіках, що розвиваються, стають все більш вирішальним джерелом експорту, робочих місць, фінансового та економічного зростання цих динамічних фігурантів сучасного світу. Ця тенденція відходу від торгових і інвестиційних потоків, в яких домінує західний споживчий попит - здатна змінити світову економіку. Посилення економічних зв'язків зі світом, що розвивається може дати той самий поштовх, якого потребує глобальна економіка, яка все ще шукає вихід з кризи і посткризових наслідків. Виникає необхідність в уточненні сутності, принципів та проблем транспортної діяльності в окремих регіонах та на рівні окремих підприємств, а також особливостей і механізмів її здійснення на ринку транспортних послуг. 
Аналіз останніх досліджень та публікацій. У вітчизняній економічній науці найбільша увага приділена дослідженню теоретикометодологічних основ транспортної діяльності. Аналізу наукових робіт, у яких досліджується вплив транспортної діяльності на просторовий розподіл економічної діяльності присвячено чимало праць [35], але розробка інтеграційних стратегій розвитку транспортних систем ще не отримала належної уваги.

Метою дослідження $є$ вивчення функціонування і розвитку локальних і національних транспортних підсистем в умовах інтеграції та формування на цій основі рекомендацій щодо розвитку форм оптимізації транспортної діяльності.

Виклад основного матеріалу. На процес транспортування впливають певні фактори, які можна згрупувати наступним чином:

І. Фактори, пов'язані з особливостями глобального і національного економічного зростання/спаду і законодавством в сфері транспорту;

II. Фактори, пов'язані з особливостями перевізного процесу i продукції транспорту;

III. Фактори, пов'язані з розглядом перевізного процесу як складної відкритої системи;

IV. Фактори, зумовлені розвитком форм власності та їх структуризацією на транспорті.

Двадцять перше століття вважається століттям становлення глобальної цивілізації на основі транснаціоналізації соціальноекономічного, політичного і культурного життя. Метою глобальної цивілізації виступає виживання і розвиток людства за умов зростання дефіциту ресурсів планети, техногенних і екологічних катастроф. До найсуттєвіших базових передумов процесу глобалізації зазвичай відносять:

- демографічний вибух у країнах, що розвиваються, який забезпечить міграцію дешевої робочої сили (людського капіталу) і розвиток ринків збуту товарів масового споживання;

- вичерпання природних ресурсів планети і загострення боротьби за їхнє використання;

- підвищення ризику всеосяжної екологічної катастрофи;

- загострення конкурентної боротьби за ринки збуту в умовах надвиробництва в розвинутих країнах;

- становлення нового технологічного укладу [2; 3] в усьому свіTi.

Прогнози майбутнього світового економічного розвитку коливаються від райдужно оптимістичних очікувань до песимістичних 
сценаріїв посткризової девіації глобальної економіки. На фоні стриманих прогнозів спеціалістів з приводу подальшого розвитку, висловлюється точка зору, що зараз світовій економіці притаманні риси, характерні для кризи 1930-х років:

1) економічна ізольованість;

2) зростаючий протекціонізм держав стосовно інтересів своїх національних виробництв;

3) падіння обсягів виробництва товарів і послуг [4].

Кожна держава, заможна чи бідна опиняється перед вибором: спробувати вижити самотужки (самостійно), чи в складі різноманітних інтеграційних форм, об'єднань, співтовариств та союзів. I перший і другий варіанти поведінки мають певні негативні і позитивні сторони. Якщо країною обирається участь в будь-якому об'єднанні, то ці союзи повинні створити наднаціональні структури управління і делегувати певну частину повноважень за рахунок національних суверенітетів членів цих співтовариств. 3 часом початковий фактичний, чи тільки задекларований паритет інтересів учасників союзу перетворюється в домінування потреб сильнішого. Ця нерівність в більшій, чи меншій мірі притаманна будь-якому об'єднанню, призводить до конфліктів, а іноді до розриву відносин в рамках союзу [5]. Тому що об'єднання економічно і структурно практично рівних учасників набагато міцніше тих, де початкова нерівність ставала причиною їх швидкого розпаду або стагнації, як сучасного Європейського Союзу, за чим ми зараз маємо можливість спостерігати - зростання протиріч між членами ЄС, збільшення конфронтації, спричиненої борговою кризою, проблемою біженців, колапсом економіки тощо.

Прогнозується, що потоки торгівлі та капіталу між регіонами світу, що розвиваються - Азією, Африкою, Близьким Сходом та Латинською Америкою - можуть зрости у 10 разів за найближчі 40 років. Ці нові зв'язки стали «версією оригінального азіатського Шовкового шляху у виконанні XXI століття», який «покликаний революціонізувати світову економіку» [5]. Взаємне зростання торгівлі та інвестицій серед країн, що розвиваються $€$ радикальним переключенням режиму традиційного функціонування світової економіки, що існував протягом кількох століть. Традиційно торгові потоки йшли між «Північчю» і «Півднем»- розвиненими країнами і країнами, що розвиваються. Природні ресурси, від спецій до шовку, поставлялися на індустріалізований Захід, який в обмін експортував текстильні та інші промислові товари. Після Другої світової війни ця система стала більш складною, завдяки покращенню систем транспорту і зв'язку. Азіатські країни, так звані індустріальні «дракони», наприклад Південна Корея, Малайзія, Тайвань і Сінгапур, перетворилися в багаті за 
рахунок аутсорсінгу (outsourcing). Ïх чисельна дешева робоча сила сприяла розвитку виробництва одягу, взуття та електроніки за західними дизайном і технологіями, і потім ці товари поставлялися споживачам розвинених країн. Подібні зв'язки продовжують охоплювати все нові частини світу, що розвиваються. Торгівля між економіками, що розвиваються - Азії та Латинської Америки, наприклад, зросла в 7 разів за 10 років (до 268 млрд доларів). Китай і Індія, в пошуках доступу до сировини і новим споживачам, вийшли на ринки Африки: обсяг торгівлі між Індією і Африкою збільшився лише з 1 млрд доларів в 2001 році до 50 млрд. доларів в 2010 році. I в подальшому експерти прогнозують значне збільшення обсягів економічної взаємодії.

У всесвітньому господарстві розширюється сфера дії загальних економічних законів (інтернаціональної вартості, глобальної конкуренції і т. ін.) і функціональних взаємозв'язків (розвиток міжнародної спеціалізації та кооперування). Рушійними силами глобалізації стали поглиблення міжнародного розподілу праці на базі зростаючої диференціації високотехнологічних кінцевих продуктів і напівфабрикатів, розвиток міжнародної транспортної інфраструктури, інформаційна революція на базі мікроелектроніки. У результаті, прискорилися міжнародний рух товарів і послуг, передача технологій виробництва. Треба дослідити динаміку світової економіки, щоб зробити висновки відносно потенціалу, місця і ролі нашої держави в міжнародному процесі переміщення матеріальних, інформаційних, фінансових i людських потоків. Існує три списки країн світу, розміщених відповідно до величини валового внутрішнього продукту (ВВП) (табл. 1).

Таблиця 1

Країни світу за обсягами ВВП (ПКС- паритетом купівельної спроможності)

Список відповідно до даних Список відповідно до даних Список відповідно до ВсесМіжнародного валютного фон- Світового банку на 2011-2017 вітньої книги фактів (ЦРУ) ду за 2017 [6]

\begin{tabular}{|c|c|c|c|c|c|c|c|c|}
\hline 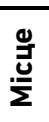 & $\begin{array}{l}\text { Країна/ } \\
\text { Регіон }\end{array}$ & \begin{tabular}{|l|} 
ВВП за ПКС \\
млрд \$
\end{tabular} & $\frac{0}{\underline{u}}$ & \begin{tabular}{|l} 
Країна/ \\
Регіон
\end{tabular} & $\begin{array}{l}\text { ВВП за ПКС } \\
\text { млрд \$ }\end{array}$ & 过 & \begin{tabular}{|l} 
Країна/ \\
Регіон
\end{tabular} & $\begin{array}{|lr|}\text { ВВП } & \text { за } \\
\text { ПКС } & \text { млрд } \\
\$ & \end{array}$ \\
\hline- & Світ & 108036,5 & - & Світ & 108464,0 & - & Світ & 107500,0 \\
\hline- & $\epsilon C$ & 18526,5 & - & $\epsilon C$ & 18423,0 & 1 & KHP & 17630,0 \\
\hline 1 & KHP & 17617,3 & 1 & KHP & 18030,9 & - & $E C$ & 17610,0 \\
\hline 2 & США & 17418,9 & 2 & США & 17419,0 & 2 & США & 17460,0 \\
\hline 3 & Індія & 7375,9 & - & Єврозона & 13106,9 & 3 & Індія & 7277,0 \\
\hline 4 & Японія & 4750,8 & 3 & Індія & 7393,07 & 4 & Японія & 4807,0 \\
\hline 5 & $\Phi \mathrm{PH}$ & 3721,6 & 4 & Японія & 4630,9 & 5 & ФPH & 3621,0 \\
\hline 6 & Росія & 3564,5 & 5 & Росія & 3745,16 & 6 & Росія & 3568,0 \\
\hline 7 & Бразилія & 3263,8 & 6 & ФРН & 3689,84 & 7 & Бразилія & 3473,0 \\
\hline 8 & Індонезія & 2676,1 & 7 & Бразилія & 3263,87 & 8 & Франція & 2587,0 \\
\hline
\end{tabular}


продовження табл. 1

\begin{tabular}{|l|l|l|l|l|l|l|l|l|}
\hline 9 & Франція & 2580,8 & 8 & Індонезія & 2676,11 & 9 & Індонезія & 2554,0 \\
\hline 10 & $\begin{array}{l}\text { Велика } \\
\text { Британія }\end{array}$ & 2548,9 & 9 & Франція & 2571,97 & $\begin{array}{l}10 \\
\text { Велика } \\
\text { Британія }\end{array}$ & 2435,0 \\
\hline$\ldots$ & $\ldots$ & $\ldots$ & $\ldots$ & $\ldots$ & $\ldots$ & $\ldots$ & $\ldots$ & $\ldots$ \\
\hline 46 & Перу & 371,3 & 45 & Україна & 370533 & 47 & Перу & 376,7 \\
\hline 47 & Україна & 370,8 & 46 & Норвегія & 333322 & 48 & Україна & 373,1 \\
\hline
\end{tabular}

Джерело: Складено автором за $[6 ; 7 ; 8]$

Тенденції розвитку світової економіки характеризуються зростанням зовнішніх господарських зв'язків та міжнародної кооперації, що сприяє зростанню транснаціональних вантажопотоків між країнами Західної Європи та Азії, Південної Європи та Ближнього Сходу.

Вигідне географічне положення України, розвинута транспортно-логістична інфраструктура повинні сприяти збільшенню обсягів вантажопотоків через її територію [9, С. 156]. Саме це і спонукає до розробки нових технологій переміщення вантажів між європейськими країнами через міжнародні коридори та реалізації розширеного спектру транспортних послуг.

Управління інтегрованими (транспортно-складськими, виробничими та іншими) логістичними процесами, здійснюваними у всіх ланках повного логістичного ланцюга, реалізується через досягнення компромісів у сфері логістичної діяльності між учасниками логістичного процесу шляхом розробки (знаходження) методології, теорії, методики та алгоритмізації процесу оптимізації ресурсних потоків усіх видів впродовж подовженого логістичного ланцюга. Управління ланцюгами постачання («Supply Chain Management - SCM») - $\epsilon$ інтеграцією ключових бізнес-процесів контрагентів ланцюга.

До теперішнього часу немає єдиної думки відносно визначення і змісту цього поняття, але багато дослідників використовують його як синонім терміну «інтегрована логістика», яка здійснюється за межами центральної або фокусної компанії, включає споживачів, постачальників і контрагентів. Логістика орієнтована на ланцюги постачання, які починаються від місця виготовлення продукції і закінчуються місцем її споживання.

Сьогодні, виникають проблеми, вирішення яких вимагає інтегрованого підходу, який, на відміну від традиційного, дозволяє оптимізувати матеріальний потік не лише у межах будь-якого підприємства, але й упродовж усього логістичного ланцюга (від місця виникнення продукції до місця ії кінцевої реалізації) шляхом виконання певних логістичних процесів обслуговування.

Організація управління, координації та взаємодії різних видів транспорту при перевезеннях вантажів - це широкий комплекс 
зв'язків і відносин (технічних, технологічних, організаційних, правових, інформаційних та інших) як між видами транспорту, так і між транспортними об'єктами і зовнішнім логістичним середовищем сферою матеріального виробництва і споживання, що забезпечують цілісність (єдність) транспортної системи.

Серед чинників, які заважають ефективній реалізації такої взаємодії, можна назвати наступні:

1) відставання темпів розвитку матеріально-технічної бази транспорту від темпів розвитку інших галузей народного господарства;

2) незбалансованість розвитку окремих видів транспорту в складі транспортного комплексу;

3) некомплексний технічний розвиток окремих видів транспорту, що призводить до порушення балансу між їх активною (рухомий склад) і пасивною (постійне обладнання і споруди) частинами;

4) незбалансований розвиток технічних засобів і обладнання взаємодіючих видів транспорту у пунктах їх стикування (транспортних вузлах);

5) відсутність єдиних показників планування спільної роботи різних видів транспорту при змішаних перевезеннях;

6) різний рівень інформаційного забезпечення логістичного транспортного процесу, непогодженість номенклатури вантажів, що перевозяться різними видами транспорту, відсутність інтегрованого інформаційного центру упродовж повного логістичного ланцюга. На ефективність функціонування усіх ланок логістичного ланцюга впливає характер інформації, яка надходить до всіх учасників та час її перетворення. Більшість підприємств, раціоналізують свою інфраструктуру за рахунок консолідації центрів обробки даних, стандартизації персональних комп'ютерів, упровадження передового досвіду експлуатації інформаційних технологій та інше. Реалізація цих методів, узятих окремо, не дає довгострокового ефекту. Тому, рекомендується аналізувати стан «зрілості» інформаційної інфраструктури, їі взаємозв'язок з потребами та загальною стратегією бізнесу [10];

7) непогодженість правових положень і економічних санкцій (заохочення) за погіршення (поліпшення) показників при виконанні змішаних перевезень вантажів взаємодіючими видами транспорту;

8) невідповідність структури парку рухомого складу сукупності вантажів, що перевозяться, та розподілу їх за партіями;

9) погіршення стану виробничих фондів, що впливає на зниження експлуатаційної надійності й безпеки транспортної системи.

Збереження таких тенденцій розвитку транспортного комплексу може стати одним із головних стримуючих чинників розвитку економіки через неможливість повного, своєчасного й якісного задоволення потреб споживачів у перевезеннях. 
Як вище вже було вказано, тенденції розвитку світової економіки характеризуються процесами інтернаціоналізації, глобалізації та універсалізації економічних процесів, які викликають взаємозалежність економік окремих держав, викликають структурні зміни в системі світової економіки і супроводжуються рецесією на тлі зростання кількості економічних криз. Вищевказані фактори обумовлюють необхідність трансформації економіки України для забезпечення ефективного розвитку країни в цілому, її регіонів і секторів національної економіки з одночасним розвитком зовнішньоекономічних зв'язків.

У динамічно змінюваних ринкових умовах, при зростаючій конкуренції, економічні агенти шукають нові підходи до організації бізнес-процесів. Створення інтегрованих транспортно-логістичних систем (ТЛС) доставки вантажів має на увазі розвиток інтеграційних зв'язків з потенційними партнерами, які можуть бути сьогоднішніми конкурентами [11]. Спільність комерційних інтересів учасників логістичного транспортного ланцюжка забезпечує можливість їх функціональної інтеграції. Це дозволяє розширити і поглибити виробничотехнологічні зв'язки, спільно використовувати ресурси, об'єднати капітали, створити один одному сприятливі умови для здійснення економічної діяльності, зняти взаємні бар'єри, збільшити прибуток і знизити витрати всіх видів ресурсів кожного учасника в процесі товарного обігу.

Суть логістичної інтеграції - це можливість ефективної співпраці окремих суб'єктів транспортного ринку з метою досягнення конкретних приватних та загальних цілей:

1) закріплення господарських зв'язків;

2) зниження транзакційних витрат;

3) посилення стимулів для отримання найбільш високого кінцевого результату;

4) концентрації ресурсів по найбільш перспективних напрямків технічної політики;

5) використання найбільш ефективної системи взаєморозрахунків, в тому числі за рахунок застосування розрахункових цін;

6) підвищення конкурентоспроможності виробників на зовнішньому ринку;

7) більш ефективного використання виробничої і соціальної інфраструктури;

8) створення такої інтеграційної структури, яка здатна не тільки забезпечити конкурентоспроможність підприємств і отримання прибутку в поточний момент, а й забезпечити стабільність на ринку і прибутковість виробничо-господарської діяльності в довгостроковій перспективі в якості головної мети інтегрування як процесу.

Створення і розвиток таких інтегрованих систем доставки ван- 
тажів з одночасною консолідацією ресурсів і можливостей всіх учасників має сприяти формуванню довгострокових конкурентних переваг, визначення переліку транспортних і супутніх послуг, пропонованих клієнтурі, швидкої адаптації спектру цих послуг для ринкових умов на рівні стратегії і тактики, забезпечення економічної стабільності і здатності постійно працювати і задовольняти потреби своїх клієнтів в перевезеннях. Результати спільних заходів повинні підтвердити взаємну вигоду співпраці і реалізувати принцип синергетичного ефекту [12].

У країнах, які $є$ лідерами світової економіки, провідну роль відіграють не окремі підприємства, а їх інтегровані структури, формування і розвиток яких характеризується активним, багатовекторним, суперечливим пошуком оптимальних механізмів функціонування, вимагає розробки теорії та методології управління, формування збалансованого (нормалізованого) розвитку підприємств - суб'єктів інтегрованої ТЛС, розробки важелів і засобів управління ними в залежності від типів застосовуваних стратегій - поглинання лідером, об'єднання рівноправних підприємств за ключовими потенціалом, об'єднання підприємств з однаковим технологічним процесом і їх потенціалів і в залежності від видів інтеграції: вертикальна (пряма і зворотна), горизонтальна, змішана (діагональна, конгломеративна), квазіінтеграція (гібридна), модальна (моно- і мультимодальна), яку, зокрема, виділяють експерти ЄС, секторальна (галузева), ринкова (товарних ринків), регіональна [13]. Розглядати транспортні структури в розрізі конкретного виду можливої інтеграції в Україні доцільно з точки зору квазіінтеграції, тому що саме цей вид не потребує обов'язкового повного контролю над власністю суб'єктів такого об'єднання і втілює так званий проектний підхід в управлінні складними відкритими системами, якими і $є$ транспортні системи.

Ретроспективний аналіз макроекономічних показників економіки України та підприємств транспортної галузі показав, що через скорочення випуску вітчизняної промислової продукції, погіршення ситуації на ринку, підвищення рівня інфляції національної валюти, зниження частки транзитних вантажопотоків, складної соціальнополітичної ситуації, незбалансованої структури витрат різних видів транспорту та інших факторів доходи транспортної галузі значно знизилися, як і якість послуг. Процес інтеграції слід розглядати як компонент інституційних змін, які реалізуються шляхом прийняття рішення про початок інтеграції та виборі форм і способів формування інститутів.

Була розроблена принципова схема механізму оптимізації функціонування і розвитку локальних транспортних підсистем (рисунок). 
Інституціонально-економічна основа збалансованого розвитку інтегрованих транспортних підсистем (закони, закономірності, тенденції)

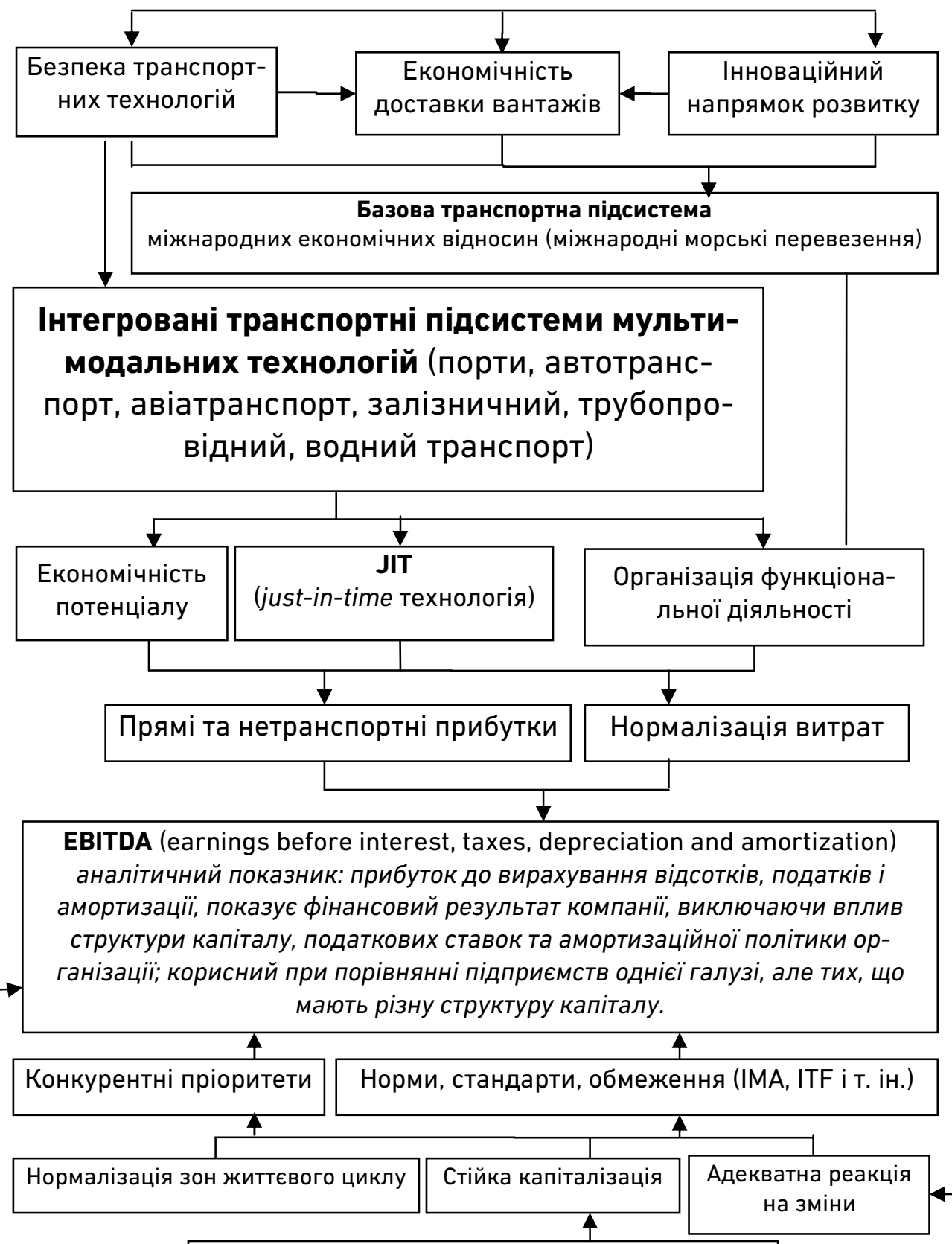

\section{Підприємницькі цілі та стратегії}

Рисунок. Механізм оптимізації функціонування і розвитку локальних транспортних підсистем

Джерело: Розроблено автором 
Тим не менш, деякі моменти в структурі знань про інтеграцію недостатньо опрацьовані: вимірювання і оцінка ефективності управління квазіінтеграцією, ефективності функціонування структури такого типу, ефективності функціонування підприємства та інших організаційних форм у квазіінтеграційній структурі.

Економічний ефект підвищення транспортабельності й технологічності в інтегрованій транспортній структурі змішаних перевезень автором пропонується визначати наступною концептуальною моделлю:

$$
E_{t r}=\sum_{n=1}^{T_{L}} \sum_{k=j}^{m}\left[\Delta P_{d_{i j}} P_{r_{i j}}+\left(C_{S_{b i j}}-C_{S_{t i j}}\right) Q_{i j}\right] a_{t i}-K_{p t r},
$$

де $T_{L}$ - життєвий цикл проекту за Адізесом І.К.;

$m$ - кількість (структура) взаємодіючих підсистем інтегрованого транспортного комплексу (проекту);

$\Delta P_{d_{i j}}$ - річна (місячна) реалізація приросту продуктивності підсистеми даного комплексу (проекту);

$P_{r_{i j}}$ - відповідна ставка нормальної прибутковості відповідно до теорії Гриффітса, EЕ;

$C_{S_{i j}}$ - собівартість одиниці транспортної роботи в базовому (b) варіанті та у варіанті конкурентного (коригованого) розвитку $(t)$;

$Q_{i j}$ - обсяг транспортної роботи;

$a_{t i}$ - коефіцієнт дисконтування поточних економічних результатів за фактором часу;

$K_{p t r}$ - інвестиційні витрати, що забезпечують інноваційні пріоритети конкурентного позиціонування.

Функціонування і розвиток проектів, підприємств, галузей, комплексів, систем, регіонів, країн і, навіть, цивілізацій (суспільних формацій) має циклічний характер, що умовно можна поділити на стадії життєвого циклу (ЖЦ), кожній з яких притаманні певні властивості і здатність впливати на кінцеву ефективність та результат діяльності суб'єкта.

Важливою, на наш погляд, є можливість керувати тривалістю і ефективністю реалізації кожної зі стадій життєвого циклу з врахуванням залежності їх впливу на кінцевий результат. Тобто, система повинна докладати зусиль для досягнення бажаного стану за допомогою управління тривалістю стадій ЖЦ і нормалізації зон ЖЦ. 
Розроблені різні підходи дослідження сутності і класифікації кожної стадії життєвого циклу, чому присвячена велика кількість праць вітчизняних та зарубіжних вчених, але, для досягнення мети нашого дослідження в подальшому доцільно використовувати положення теорії американського вченого Іцхака Кальдерона Адізеса, в колі наукових інтересів і розробок якого $є$ управління змінами.

Концепт життєвого циклу І.К. Адізеса [15], або так званий код PAEI (код Адізеса), базується на забезпеченні результативності й ефективності організації у коротко- та довгостроковому періоді, що втілюється за рахунок виконання системою менеджменту чотирьох функцій:

1) задоволення потреб ринку і клієнтів, орієнтація на кінцеві результати роботи, ( $\mathrm{P}$ - providing needs),

2) гарантування дотримання встановлених порядків, контроль процесів (A-administration);

3) заохочення підприємництва за рахунок нових ідей, аналізу навколишнього середовища, визначення сильних та слабких сторін проекту, організації і визначення на основ цього стратегії дій (Е entrepreneurship);

4) створення у компанії атмосфери співпраці, інтеграції ідей, вирішення спірних питань для довгої ефективної роботи (I integration).

Причому перші дві відносять до функцій короткострокової дії (впливу), останні дві - до довгострокової. Проявом високої функціональності концепції PAEI $€$ неоднаковий рівень розвитку функцій на кожному етапі життєвого циклу підприємства (проекту). Але гармонійне поєднання всіх функцій є гарантом успішного існування проекту, системи, організації на всіх етапах ЖЦ. Концепт Адізеса дає змогу не тільки прогнозувати майбутній стан транспортної системи, але й ефективно керувати змінами для досягнення оптимальних результатів.

Скористатися перевагами вищезгаданої концепції Адізеса доцільно при застосуванні інтеграційних стратегій розвитку транспортних систем. Інтегрований підхід в логістиці вимагає об'єднання різних функціональних областей та їх учасників у рамках єдиної транспортно-логістичної системи з метою ії оптимізації.

Висновки. Державна політика в сфері розвитку транспортних систем повинна виявити найбільш гострі проблеми, з якими стикається транспортний комплекс і виробити заходи для їх вирішення шляхом державного інвестування в розвиток і реформування транспортної інфраструктури, а також інституційної ліквідації «вузьких місць». 
Інтеграційні об'єднання можуть вирішити ряд загальних для всіх суб'єктів-учасників тієї чи іншої транспортної структури бар'єрів, шляхом консолідації спільних зусиль, спрямованих на усунення їхніх насущних проблем, виділення взаємовигідних напрямків співпраці і інших механізмів ефективної взаємодії.

Незважаючи на глибокі кризові явища в українському транспортному комплексі, є вагомі причини, для наступних висновків:

- в даний час існують об'єктивні історичні передумови і економічні потреби для формулювання стратегічного завдання відновлення України як потужної транспортної і промислової держави, здатної вплинути на соціально-економічний розвиток та забезпечити національну безпеку;

- в Україні зберігся певний ресурс («фундамент») транспортного комплексу України, чого достатньо для нового відродження транспортної діяльності держави.

1. Бакаєв О. О., Пірожков С. І., Ревенко В. Л. Міжнародні транспортні коридори - особливий пріоритет України на шляху інтеграції у світову економічну систему. Стратегічна панорама. 1999. № 4. С. 37-56. 2. Василенко В. Технологические уклады в контексте стремления экономических систем к идеальности. Соціально-економічні проблеми і держава : журнал. Тернопіль, 2013. Т. 8. № 1. С. 65-72. 3. Меньшиков С. М., Клименко Л. А. Длинные волны в экономике: Когда общество меняет кожу. 2-е изд. М. : ЛЕНАНД, 2014. 288 c. 4. Lagarde Kristine. Chinese economy: Fears grow that China is overheating. The Financial Times, January 20, 2011. 5. Антошкина Л. И. Экономические союзы в разрезе мировой истории и современности. Проблемы и перспективы развития сотрудничества между странами Юго-Восточной Европы в рамках Черноморского экономического сотрудничества и ГУАМ : сб. науч. тр. Албена-Донецк : ДонНУ, РФ НИСИ в Г. Донецке, 2012. 366 с. 6. Report for Selected Country Groups and Subjects (PPP valuation of country GDP). IMF. Процитовано April 8, 2015. 7. "Gross domestic product 2014, PPP", World Bank, accessed on 2 July 2015. Data.worldbank.org. Процитовано July 2, 2015. European Union calculated by sum of individual countries. 8. Field listing - GDP (PPP exchange rate), CIA World Factbook. 9. Крикавський Є. В., Чорнописька Н. В. Логістичні системи : навч. посіб. для студ. екон. спец. Нац. ун-т «Львівська політехніка». Л. : Львівська політехніка, 2009. 264 с. 10. Григорак М. Ю. Костюченко Л. В., Соколова О. Є. Логістична інфраструктура : навч. посібник. К. : Логос, 2013. 400 с. 11. Миротин Л. Б., Сергеев В. И. Основы логистики : учебное пособие / под ред. Л. Б. Миротина, В. И. Сергеева. М. : ИНФРА-М, 2000. 200 с. 12. Мордвицька Ю. С. Функціональний підхід до удосконалення системи управління логістичними бізнес-процесами інтегрованих холдингів. Теоретичні і практичні аспекти економіки та інтелектуальної власності : науковий журнал. 2016. № 13. С. 61-65. 13. Волинчук Ю. В. Реінжиніринг логістичних бізнес-процесів підприємства. Логістика: теорія $i$ практика : науковий журнал. 2012. № 2. URL: http://www.nbuv.gov.ua/portal/Soc_Gum/ekfor/2013_1/34.pdf. (дата звер- 
Серія «Економічні науки»

Випуск 4(84) 2018 р.

нення: 05.06.2019). 14. Shevchenko I. V. Actuality of creation of integrated transport and logistic systems of cargo transportation for ensuring competitiveness of transport enterprises. Технології та інфраструктура транспорту : матеріали міжнародної науково-технічної конференції, Харків, (1416 травня 2018 р.). Харків : УкрДУЗТ, 2018. С. 141-143. 15. Ицхак К. Адизес. Управление жизненным циклом корпораций. С-Пб, Изд-во «Питер», 2013. $700 \mathrm{c}$.

\section{REFERENCES:}

1. Bakaiev 0. O., Pirozhkov C. I., Revenko V. L. Mizhnarodni transportni korydory - osoblyvyi priorytet Ukrainy na shliakhu intehratsii u svitovu ekonomichnu systemu. Stratehichna panorama. 1999. № 4. S. 37-56. 2. Vasilenko V. Tekhnolohicheskie uklady $\mathrm{v}$ kontekste stremleniia ykonomicheskikh sistem $\mathrm{k}$ idealnosti. Sotsialno-ekonomichni problemy i derzhava : zhurnal. Ternopil, 2013. T. 8. № 1. S. 65-72. 3. Menshikov S. M., Klimenko L. A. Dlinnye volny v ekonomike: Kohda obshchestvo meniaet kozhu. 2-e izd. M. : LENAND, 2014. 288 s. 4. Lagarde Kristine. Chinese economy: Fears grow that China is overheating. The Financial Times, January 20, 2011. 5. Antoshkina L. I. Ekonomicheskie soiuzy $v$ razreze mirovoi istorii i sovremennosti. Problemy $i$ perspektivy razvitiia sotrudnichestva mezhdu stranami Yuho-Vostochnoi Ev-ropy $v$ ramkakh Chernomorskoho ekonomicheskoho sotrudnichestva i HUAM : sb. nauch. tr. Albena-Donetsk: DonNU, RF NISI v h. Donetske, 2012. 366 s. 6. Report for Selected Country Groups and Subjects (PPP valuation of country GDP). IMF. Protsytovano April 8, 2015. 7. "Gross domestic product 2014, PPP", World Bank, accessed on 2 July 2015. Data.worldbank.org. Protsytovano July 2, 2015. European Union calculated by sum of individual countries. 8. Field listing - GDP (PPP exchange rate), CIA World Factbook. 9. Krykavskyi Ye. V., Chornopyska N. V. Lohistychni systemy : navch. posib. dlia stud. ekon. spets. Nats. un-t «Lvivska politekhnika». L. : Lvivska politekhnika, 2009. 264 s. 10. Hryhorak M. Yu. Kostiuchenko L. V., Sokolova O. Ye. Lohistychna infrastruktura : navch. posibnyk. K. : Lohos, 2013. 400 s. 11. Mirotin L. B., Serheev V. I. Osnovy lohistiki : uchebnoe posobie / pod red. L. B. Mirotina, V. I. Serheeva. M. : INFRA-M, 2000. 200 s. 12. Mordvytska Yu. S. Funktsionalnyi pidkhid do udoskonalennia systemy upravlinnia lohistychnymy biznes-protsesamy intehrovanykh kholdynhiv. Teoretychni i praktychni aspekty ekonomiky ta intelek-tualnoi vlasnosti : naukovyi zhurnal. 2016. № 13. S. 61-65. 13. Volynchuk Yu. V. Reinzhynirynh lohistychnykh biznes-protsesiv pidpryiemstva. Lohistyka: teoriia i praktyka : naukovyi zhurnal. 2012. № 2. URL: http://www.nbuv.gov.ua/portal/Soc_Gum/ekfor/2013_1/34.pdf. (data zvernennia: 05.06.2019). 14. Shevchenko I. V. Actuality of creation of integrated transport and logistic systems of cargo transportation for ensuring competitiveness of transport enterprises. Tekhnolohii ta infrastruktura transportu : materialy mizhnarodnoi naukovo-tekhnichnoi konferentsii, Kharkiv, (14-16 travnia 2018 r.). Kharkiv : UkrDUZT, 2018. S. 141-143. 15. Itskhak K. Adizes. Upravlenie zhiznennym tsiklom korporatsii. S-Pb, Izd-vo «Pyter», 2013.700 s.

Рецензент: д.е.н., професор Грицюк П. М. (НУВГП) 
Kovshun N. E., Candidate of Economics (Ph.D.), Professor (National University of Water and Environmental Engineering, Rivne),

Shevchenko I. V., Applicant (National University of Water and Environmental Engineering, Rivne)

FUNCTIONING AND DEVELOPMENT OPTIMIZATIONS OF LOCAL AND NATIONAL TRANSPORTATION SUBSTANCES IN THE CONDITIONS OF INTEGRATION

The necessity of improving the regulatory, legislative, organizational and economic regulation of the transport market is proved. The factors that influence the efficiency of the transportation process are analyzed. The expediency of using the concept of Adizes in the development of in-migration strategies for the development of transport systems is explored.

Keywords: local transport subsystems, concept of Adizes, efficiency of transportation process, integration strategies for the development of transport systems.

Ковшун Н. Е., к.э.н., профессор (Национальный университет водного хозяйства и природопользования, г. Ровно), Шевченко И. В., соискатель (Национальный університет водного хозяйства и природопользования, г. Ровно)

ОПТИМИЗАЦИЯ ФУНКЦИОНИРОВАНИЯ И РАЗВИТИЯ ЛОКАЛЬНЫХ И НАЦІОНАЛЬНЫХ ТРАНСПОРТНЫХ ПОДСИСТЕМ В УСЛОВИЯХ ИНТЕГРАЦИИ

Доказана необходимость совершенствования нормативнозаконодательного, организационного и хозяйственного регулирования транспортного рынка. Проанализированы факторы, которые влияет ют на эффективность процесса транспортировки. Исследована целесообразность использования концепта Адизеса при разработке интеграционных стратегий развития транспортных систем. Ключевые слова: локальные транспортные подсистемы, концепция Адизеса, эффективность процесса транспортировки, интеграционные стратегии развития транспортных систем. 